\title{
Estimated Valuation of the Cost of Road Construction with the Use of Composite Cationic Bituminous Structures
}

\author{
Anna Vorotynseva ${ }^{1, *}$, Andrey Ovsiannikov ${ }^{1}$ and Vladimir Bolgov ${ }^{1}$ \\ ${ }^{1}$ Voronezh State Technical University, 14, Moskovsky prospect, Voronezh, 394026, Russia
}

\begin{abstract}
Annotation. The need for formation of prices for road construction works producing, by using composite of cationic bituminous structures, is dictated by absence of this type of work in estimate-normative base, due to the fact that this type of materials had never been used before. Estimated specifications could be used either for determination of work cost or for substantiation of efficiency of using new type of materials. This paper provides basic concepts, related to formation of estimate-normative base for determination of construction and installation works cost, particularly road construction works, also it shows formation of coating installation prices by using composite of cationic bituminous emulsions.
\end{abstract}

\section{Introduction}

Modern system of estimated specification is the foundation of definition of construction and installation works cost, particularly road construction works cost. Current system can't cover the whole spectrum of modern constructive materials, particularly new materials that had never been used before in constructing or in other definite type of works.

The development of estimated specification for road constructing work production with using composite cationic bituminous structures is determined by advantages of this material over traditional technologies of hot and cold road asphalt paving:

1. There is no need in adherence to temperature conditions, due to the fact that this method can be used either in worm or in cold weather conditions. The repairing of road cover can be produced in high humidity conditions at positive ambient temperatures [1,9].

2. You can exploit roads 2 hours after finishing repairing works, which is especially actual on increased workload roads $[2,6,11]$.

3. The value of bitumen using is highly reduced compared to hot and cold asphaltconcrete mixtures structure $[1,9]$.

4. The use of previously recorded cover becomes possible, which significantly reduces prime cost and increases ecological effect, reduces the measure of road repairing construction's waste $[2,6,11]$.

\footnotetext{
${ }^{*}$ Corresponding author: allslavin@mail.ru
} 
5. It eliminates the need for additional installation of coatings of hot and cold asphaltconcrete mixtures similar to existing technology of road installation with recycling using $[3,6$, 9].

6. The coating is more durable than hot and cold asphalt paving (alternative covers are usually used for 5 years, though hot and cold asphalt paving's life time is only 3 years, which highly increases the economic effect of using offered technology) $[3,6,9]$.

7. Covers with composite structures based on cationic bituminous emulsions in all types of repairing works gives more durable result compared with traditional technologies due to the fact of better grip $[4,6]$.

This paper shows the process of formation of prices for road construction works with using composite cationic bituminous structures, and also gives a comparison of work costs for road covering installations with using new materials and traditional methods of hot and cold asphalt-concrete mixtures.

\section{Methods}

There are several ways to define the road works cost. We used the method of the cost determination based on estimated specifications compiling, which includes:

1. The development of elemental estimated specifications;

2. The determination of estimated prices for used resources;

3. The formation of unitary prices.

Estimated specifications is the complex of estimated prices, which are used for determination of estimated construct costs along with rules and contributions, which include necessary regulations $[5,14]$.

The main estimated normative, used for road work cost's determination is estimated price, which represents the amount of funds, sufficient for all resources purchase (material, labor and technical), which are necessary for execution special work types $[7,10,13]$. The scheme of prices formation is represented on figure 1.
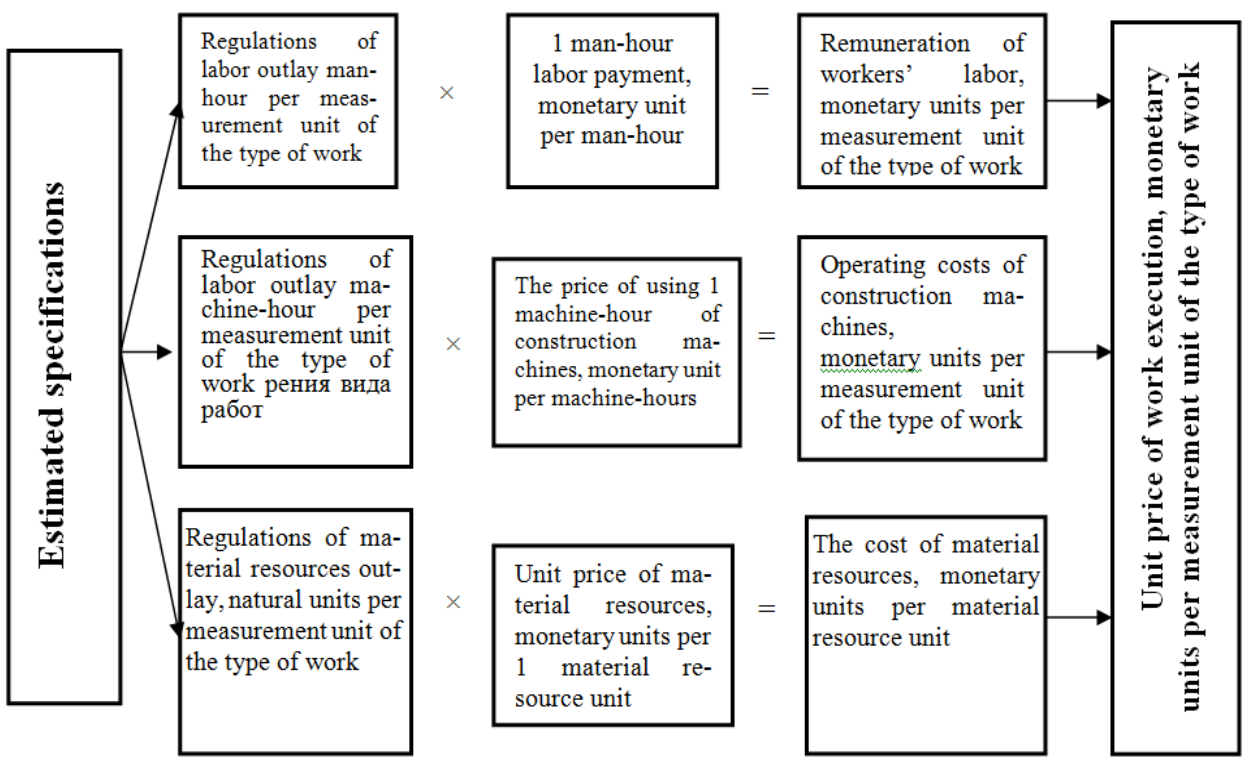

Fig. 1.Forming prices scheme 


\section{Results}

Estimated specifications are developed for every several measurer of construction-installation and road repairing works. In the reviewing case we will use $1000 \mathrm{~m} 2$ unit of measurement, which suggests work's execution in value of $70 \mathrm{~m} 3$ with thickness of the covering of $7 \mathrm{~cm}$ and extension of the road about $167 \mathrm{~m}$ with middle width of the road of $6 \mathrm{~m}$. While forming the prices, we use current normative base, corrected to the current price level and represented in dollar equivalent, which was motivated by the possibility of applying this technology not only in Russian Federation but also abroad. The forming of estimated specifications for new types of work (recycling and coverings with using composite structures had first priority, due to the fact that hot and cold coverings already have their prices.

The consumption and price of materials needed to perform road work in different ways are shown in Table 1.

We offer Germany's company's WIRTGEN productions as main equipment for work producing. It was rather efficient while used on road constructing machine market. This equipment allows to solve wide range of tasks, such as strengthen the soil and road covers installations. You can get high-class building material, instead of low quality soil, with the help of this machines. Additives and binders are cement, lime and water. Working as a cold recycler, WR series machines transform worn out layers of asphalt-concrete into high-class layers with a large bearing capacity, regardless of their size and layers thickness. The most suitable for our needs is WR 200 machine. We calculated the cost of machine-hours is $\$$ 169.45, and the estimated rate -1.67 machine-hours for $1000 \mathrm{~m} 2$ of pavement.

Table 1. Volume and price of materials used

\begin{tabular}{|c|c|c|c|c|}
\hline \multirow[b]{2}{*}{ Name of materials } & \multicolumn{3}{|c|}{ Consumptoin of materials, $\mathrm{m} 3$ for $100 \mathrm{~m} 3$ of cover } & \multirow{2}{*}{$\begin{array}{l}\text { Price } \\
\text { in } \\
\text { dollar } \\
\text { s per } 1 \\
\text { ton }\end{array}$} \\
\hline & $\begin{array}{l}\text { Hot } \\
\text { asphalt- } \\
\text { concret } \\
\text { e mixes }\end{array}$ & $\begin{array}{l}\text { Cold } \\
\text { asphalt- } \\
\text { concret } \\
\text { e mixes }\end{array}$ & $\begin{array}{l}\text { Compositecationicbituminousstructur } \\
\text { es }\end{array}$ & \\
\hline Cement & 2 & - & 3 & 100 \\
\hline Sand & - & 14 & - & 15 \\
\hline Bitumen & 5,5 & 6 & 2 (for emulsifying) & 160 \\
\hline Diesel fuel & - & 3 & & 630 \\
\hline $\begin{array}{l}\text { Butadiene- } \\
\text { styrenethermoplasticelastom } \\
\text { er }\end{array}$ & - & 0,2 & - & 200 \\
\hline Macadam & 92,5 & 76,8 & 27 & 20 \\
\hline Water & - & - & 2 (for emulsifying) & 0,5 \\
\hline Asphaltgranulate & - & - & 66 & 0 \\
\hline Emulsifier & - & - & 0,05 (for emulsifying) & 800 \\
\hline
\end{tabular}

Following estimated specifications have been developed on the base of presented data and pre-existing estimated standards:

1. Disassembly of asphalt-concrete covers and foundations with later processing of removed layer - recycling, $1000 \mathrm{~m} 3$ (Table 2).

2. Design of covers with use of composite cationic bituminous structures (Table 3). 
Table 2. Development of asphalt-concrete covers and foundations with later processing of removed layer - recycling, $1000 \mathrm{~m} 2$

\begin{tabular}{|l|c|c|}
\hline \multicolumn{1}{|c|}{ Name of resource } & Units & Amount \\
\hline Recycling tools - machines WR 200 & Machine-hour & 1,67 \\
\hline Machinist's labor cost & Man-hour & 1,67 \\
\hline
\end{tabular}

Table 3. Design of covers with use of composite cationic bituminous structures, $1000 \mathrm{~m} 2$

\begin{tabular}{|l|c|r|}
\hline \multicolumn{1}{|c|}{ Name of resource } & Units & Amount \\
\hline Workers labor costs (middle 2,9) & Man-hour & 61,84 \\
\hline Machinists labor costs & Man-hour & 6,53 \\
\hline $\begin{array}{l}\text { Automotive cranes at work on other types of } \\
\text { construction 10 t }\end{array}$ & Machine-hour & 0,04 \\
\hline Hand sprayers & Machine-hour & 0,56 \\
\hline Road rollers. Self-propelled, smooth & Machine-hour & 2,55 \\
\hline Asphalt concrete pavers & Machine-hour & 3,19 \\
\hline Tractor with mounted road brushes & Machine-hour & 0,75 \\
\hline Board cars, capacity 5t & Machine-hour & 0,07 \\
\hline Kerosene for technical purposes, brands KT-1, KT-2 & $\mathrm{t}$ & 0,00059 \\
\hline Square billets forgings, weight: 1,8 kg & $\mathrm{t}$ & 0,00613 \\
\hline Bitumen & $\mathrm{t}$ & 0,14 \\
\hline $\begin{array}{l}\text { Bars softwoodlength: 4-6,5 m, wideness 75-150 mm, } \\
\text { thickness 40-75 mm, III grade }\end{array}$ & $\mathrm{m} 3$ & 0,15 \\
\hline Asphalt concrete mixture & $\mathrm{t}$ & 165 \\
\hline
\end{tabular}

Estimated prices for new and pre-existing types of work are listed in Table 4.

Table 4. Producing road repairing work prices (per $1000 \mathrm{~m} 2$ )

\begin{tabular}{|c|c|c|c|c|c|c|c|}
\hline \multirow[b]{2}{*}{$\mathbf{N}$} & \multirow{2}{*}{$\begin{array}{l}\text { Denomination and } \\
\text { characteristic of construction } \\
\text { works }\end{array}$} & \multirow{2}{*}{$\begin{array}{l}\text { Direct } \\
\text { costs, } \\
\text { dollar. }\end{array}$} & \multicolumn{4}{|c|}{ Including, dollar. } & \multirow{2}{*}{\begin{tabular}{|l} 
Workers \\
Labor costs \\
man-hours
\end{tabular}} \\
\hline & & & $\begin{array}{l}\text { Workers } \\
\text { salary }\end{array}$ & \multicolumn{2}{|c|}{$\begin{array}{l}\text { Machine } \\
\text { exploitation }\end{array}$} & Materials & \\
\hline \multicolumn{8}{|c|}{ Asphalt-concrete coverings and foundations dismantling } \\
\hline 1 & $\begin{array}{l}\text { Followed by the removal of } \\
\text { the pulled off layer }\end{array}$ & 1344,79 & 449,99 & 894,80 & 98,17 & & 214,82 \\
\hline 2 & $\begin{array}{l}\text { Followed by the removal of } \\
\text { the pulled off layer with } \\
\text { shipment }\end{array}$ & 841,60 & 315,10 & 526,50 & 102,95 & & 125,86 \\
\hline 3 & Followed by recycling & 282,98 & & 282,98 & 11,69 & & \\
\hline \multicolumn{8}{|c|}{\begin{tabular}{|l|l} 
Coverings design \\
\end{tabular}} \\
\hline 4 & $\begin{array}{l}\text { Hot asphalt-concrete } \\
\text { mixtures }\end{array}$ & 2454,65 & 78,80 & 216,90 & 55,37 & 2158,95 & 67,025 \\
\hline 5 & $\begin{array}{l}\text { Cold asphalt-concrete } \\
\text { mixtures }\end{array}$ & 3680,80 & 185,48 & 79,32 & 17,90 & 3416,00 & 61,84 \\
\hline 6 & $\begin{array}{l}\text { With using composite of } \\
\text { cationic bituminous } \\
\text { emulsions }\end{array}$ & 1149,75 & 185,48 & 79,32 & 17,90 & 884,95 & 61,84 \\
\hline
\end{tabular}

\section{Discussion}

Estimated calculations for producing works were built on the basis of prices represented in Table 4, there are three compared methods.

Following results for the unit cost of $1 \mathrm{~m} 2$ of pavement were obtained on the basis of the estimated calculations:

- hot asphalt concrete mixtures -- 3,30 \$, including materials - 2,16\$;

- cold asphalt concrete mixtures -- 4,52 \$, including materials - 3,42\$; 
- composite cationic bituminous structures -- 1,46 \$, including materials $-0,88 \$$.

Economical effect of composite cationic bituminous structures installing makes up comparing:

- to use of hot coverings $-1,87 \$$, including materials $-1,28 \$$

- to use of cold coverings $-3,09 \$$, including materials $-2,54 \$$.

Using suggested technology of producing road covering attracts economy in value 11200$18500 \$$ per $1 \mathrm{~km}$ of repaired roads, consequently $[2,8,12]$.

\section{Conclusion}

Applying this new method based on using composite of cationic bituminous emulsions and recycling technology can help to reduce time limits for producing repairing works of road covering and their prompt commissioning. It can help to produce repairing works regardless of the climatic conditions, to provide economic and ecologic effect.

\section{References}

1. M. Aladdess. Engineering Systems and Structures, 3(16), 38-43, (2014)

2. A. Vorotynseva, M. Aladess.Finances, Economics, Strategy, 6, 48-54, (2016).

3. V. Gasilov, A. Vorotynseva, A. Ovsyannikov. Estimated work in constructing: tutorial, Voronezh State University of architecture and construction, Voronezh,(2016)

4. Public elemental estimate standards. 81-02-27-2001. Car roads. The Ministry of Construction and Housing and Communal Services of Russian Federation, Moscow, (2014)

5. A. Ovsyannikov, A. Vorotynseva, D. Kuzmina. Pricing and budget normalization in the construction of: practical work.Voronezh State University of architecture and construction, Voronezh,(2016)

6. V. Podolskiy, M. Aladess.Engineering Systems and Structures, 4(17), 96-105, (2014)

7. Federal unit prices.81-02-27-2001. Car roads, The Ministry of Construction and Housing and Communal Services of Russian Federation, Moscow, (2014)

8. A. Chomicz-Kowalska, K. Maciejewski. Procedia Engineering, 108, 436-444, (2015)

9. A. Yuliestyan, A. A. Cuadri, M. García-Morales, P.Partal. Transportation Research Procedia, 14, 3512-3518, (2016)

10. O. V. Didkovskaya, O. A. Mamayeva, M. V. Ilyinaю. Procedia Engineering, 153, 131135,(2016)

11. A.T. Nyoman, I. Nyoman, W. Negara, I. PutuSuarjana. Procedia Engineering, 95, 479488, (2014)

12. P. Buczyński. Procedia Engineering, 161, 54-59, (2016)

13. R. Scrivo, A. Rugolo, A.Viglianisi.Procedia. Social and Behavioral Sciences, 223, 187192, (2016)

14. S.Sunarjono. Procedia Engineering, 54, 698,-710, (2013) 